\title{
Financing an efficient adaptation programme to climate change: A contingent valuation method tested in Malaysia
}

\author{
Hasanul Banna ${ }^{1, *}$, Rafia Afroz ${ }^{2}$, Muhammad Mehedi Masud ${ }^{2}$, Md. Sohel Rana ${ }^{3}$, Eric H.Y. Koh ${ }^{1}$ and \\ Rubi Ahmad ${ }^{1}$ \\ ${ }^{1}$ Department of Finance and Banking, Faculty of Business and Accountancy, University of Malaya, 50603 Kuala Lumpur, Malaysia \\ 2 Department of Economics, International Islamic University Malaysia, 53100 Kuala Lumpur, Malaysia \\ ${ }^{3}$ Department of Business Strategy and Policy, Faculty of Business and Accountancy, University of Malaya, 50603 Kuala Lumpur, \\ Malaysia
}

\begin{abstract}
This paper assesses farmers' willingness to pay for an efficient adaptation programme to climate change for Malaysian agriculture. We used the contingent valuation method to determine the monetary assessment of farmers' preferences for an adaptation programme. We distributed a structured questionnaire to farmers in Selangor, Malaysia. Based on the survey, 74\% of respondents are willing to pay for the adaptation programme with several factors such as socio-economic and motivational factors exerting greater influences over their willingness to pay. However, a significant number of respondents are not willing to pay for the adaptation programme. The Malaysian government, along with social institutions, banks, NGOs, and media could come up with fruitful awareness programmes to motivate financing the programme. Financial institutions such as banks, insurances, leasing firms, etc. along with government and farmers could also donate a substantial portion for the adaptation programme as part of their corporate social responsibility (CSR).
\end{abstract}

Keywords: adaptation / agriculture / climate change / farmers / contingent valuation method / financing

Résumé - Financement d'un programme d'adaptation au changement climatique : une méthode d'évaluation contingente testée en Malaisie. Ce document vise à évaluer la volonté des agriculteurs de Malaisie à contribuer au financement d'un programme d'adaptation au changement climatique. La méthode d'évaluation contingente a été utilisée pour déterminer les préférences économiques des agriculteurs en matière d'adaptation. Un questionnaire structuré a été utilisé avec les agriculteurs de Selangor, en Malaisie. Soixante-quatorze pour cent d'entre eux sont prêts à financer un programme d'adaptation. Des facteurs tels que la dynamique socio-économique et la motivation sont les plus influents. Cependant, nombre d'agriculteurs ne sont pas prêts à payer pour un programme d'adaptation. Le gouvernement de Malaisie, les institutions sociales, les banques, les ONG et les médias pourraient mettre en place des programmes de sensibilisation. Les institutions financières comme les banques, les assurances, les sociétés de crédit, etc. pourraient aussi faire des dons à un programme d'adaptation au changement climatique au titre de la responsabilité sociale des entreprises (RSE).

Mots clés : adaptation / agriculture / changement climatique / agriculteurs / méthode d'évaluation contingente / financement

\section{Introduction}

Globally, there are many concerns for the negative effects of climate change on agricultural productivity (Gornall et al., 2010) and farmers' welfare (Menapace et al., 2015). The extreme weather conditions, the unexpected temperature increase, and the rainfall fluctuations potentially threaten the agro-economy (Lobell et al., 2011). Food and Agriculture

*Corresponding author: bannaje@yahoo.com
Organization (FAO, 2015) predicts that grain and maize yields could drop by up to $10 \%$ in South-East Asia by 2030 due to the poor rains and heatwave conditions. Similar findings have been reached by Intergovernmental Panel on Climate Change's (IPCC) recent publications and reports (IPPC, 2014). On these grounds, climate variability poses major challenges to developing countries as their economies are agro-based (Stern and Treasury, 2006).

In Malaysia, at least one-third of the country's population depends on the agricultural sector for their livelihood (Singh, 2014). Statistics show that approximately $39 \%$ of total land is 
cultivated for rubber, oil palm, cocoa, coconut, fruits and vegetables (Austin and Baharuddin, 2012). The consequences of extreme climate change such as floods and unexpected temperatures could seriously affect the Malaysian economy and society. For example, an estimated RM 84 million (RM $10=\$ 2.4$ ) worth of agricultural production was damaged due to the recent flood that affected 7000 farmers of Malaysia (Singh, 2014). According to the Initial National Communication (INC) (2000), the rainfall and temperature are projected to rise between -1 and $32 \%$ and +0.6 and $3.4{ }^{\circ} \mathrm{C}$ in 60 years, respectively, and the sea level is expected to rise approximately $13-94 \mathrm{~cm}$ in 100 years in Malaysia. Excessive rainfall affects the production of yields such as crude palm oil, and prolonged droughts affect crops that need wet conditions such as rice, vegetables, and others (Singh, 2014). The increase in temperature also affects the rice grain yield. The Malaysian Agricultural Research and Development Institute (MARDI) has projected that the rice yields in peninsular Malaysia will decline by 9 to $10 \%$ for each one degree Celsius rise (Abdullah, 2007). Meanwhile, the rise of sea level due to climate change could force the deserting of low-laying planted areas such as rice, corn coconut, and others. Climate change is especially expected to impact the productivity of the rice yields in Malaysia (Tao et al., 2008).

Climate change directly or indirectly affects the social and economic sustainability of farmers. The line of effects may be multiple including crop failures, increase costs of production, reduction in farmer income, and increase in seasonal unemployment rate (Alam et al., 2011; Siwar et al., 2009). Farmers are nevertheless little concerned about climate change due to inadequate awareness of climate change issues, lack of local knowledge, and inefficient institutional capacity (Kurukulasuriya and Rosenthal, 2013). Thus, adaptation strategies are highly needed to address the looming risk of climate change on farmers.

The impact of climate change on agricultural production has been discussed and empirically tested extensively on the quantification of damages (e.g.Fankhauser, 2013; Luers et al., 2003) rather than addressing farmers' perception and attitude toward the issue and their willingness to pay for an efficient adaptation programme. Additionally, with the exception of a few studies (e.g.Acquah, 2011; Le Dang et al., 2014), most of the research work (e.g.Arbuckle Jr et al., 2013; Barnes et al., 2013; Saleh Safi et al., 2012; Wheeler et al., 2013) has focused on developed nations, instead of developing nations. Studies on climate change adaptation methods in developing countries are scarce. Thus, our study focuses on farmer's perceptions and their financing willingness for an adaptation programme in Malaysia.

The advantages of adaptation are reduction of vulnerability, raising resilience, restraining the risk of climate change impact on lives and livelihood, and grasping the advantages of opportunities posed by actual and expected climate change. This study (i) assesses the willingness to pay (WTP) of the farmers for an efficient adaptation programme to climate change in Selangor, Malaysia and (ii) determines the factors that influence their WTP.

The study of WTP of farmers is important, especially in the context of limited research work on this area in Malaysia. To develop a comprehensive understanding for expected climate change adaptation programme and motivational factors that influence farmer's WTP, we test the following two hypotheses:

$-\mathrm{H}_{1}$ : there is a positive relationship between socio-economic factors and WTP for climate change adaptation programme;

$-\mathrm{H}_{2}$ : there is a positive relationship between motivational factors and WTP for climate change adaptation programme.

\section{Methodology}

\subsection{Contingent Valuation Method}

Contingent Valuation Method (CVM) was employed to estimate the WTP of farmers as applied to environmental valuation (Carson, 2012). CVM studies take a variety of formats, including open-ended, dichotomous choice, multiplebounded dichotomous choice, iterative bidding, and payment cards. The payment card approach offers higher efficiency despite some biasness.

The CVM is widely used in developed countries to quantify the benefits of non-marketed environmental goods that enter directly into cost-benefit calculations (Carson et al., 2010). However, there is a possibility to have a hypothetical bias while using CVM. "Short cheap talk" in accordance with Aadland and Caplan (2006) has been employed in our survey questionnaires to avoid the potential problem of hypothetical bias. After completing the hypothetical questions regarding their WTP for a planned adaptation programme to climate change, we then randomly selected and created a short cheap talk group. The group was asked the following short-cheap-talk script, which was read prior to the ensuring WTP question:

"As you prepare to answer the next few questions, please keep in mind that in previous surveys we have found that the amounts that people SAY they are willing to pay for a planned adaptation programme to climate change are sometimes different from the amounts that they would ACTUALLY be willing to pay when an adaptation programme to climate change becomes available in their community. For this reason, as I read the following adaptation programme fees, please imagine you are ACTUALLY paying them."

We used short-cheap-talk script as it is effective for the farmers (Aadland and Caplan, 2006). Further explanation regarding method of provision, payment vehicle, decision rule, and the period of payment were presented to the farmers through a payment card (Boyle, 2003). The payment card developed in this study is in accordance with Rowe et al. (1996). It presents a list of values from which respondents choose an amount that best represents their maximum WTP. Payment card was designed with an exponential response scale that contains 24 cells. An exponential response scale is consistent with this hypothesis of measurement error increasing with WTP values. The values of the cells 2 through to 22 are computed (Tab. 1) by the following equation:

$$
V_{n}=V_{1} \times[1+R]^{n-1},
$$

where, $V_{n}=$ bid value, $V_{1}=1, R=$ range selected for the payment card so that largest value on the payment card is $(1.2860)^{21}=200$. 
Table 1. The various types of amount that were asked to the respondents to pick up (Payment card).

Tableau 1. Les différents types de montant pouvant être choisis par les participants (carte de paiement).

Ranges of pick up amount

\begin{tabular}{llllllll}
\hline RM 0 & RM 2 & RM 5 & RM 10 & RM 20 & RM 45 & RM 95 & RM 200 \\
RM 0.5 & RM 3 & RM 6 & RM 12 & RM 25 & RM 55 & RM 120 & More than RM 200 \\
RM 1 & RM 4 & RM 8 & RM 16 & RM 35 & RM 75 & RM 155 & Do not know \\
\hline
\end{tabular}

Source: author's calculation using equation (1).

The payment vehicle was the electricity bill of the farmers. Each firm can pay a lump sum amount incorporated in their electricity bill on a regular basis. The fund will be managed by the climate change adaptation programme for the agricultural sector in Malaysia.

\subsection{Site selection and data collection}

The survey questionnaire was conducted among the farmers in the Integrated Agricultural Development Area (IADA), Selangor, Malaysia, which covers approximately 100,000 ha. Of which 20,000 ha is for paddy, 55,000 ha for palm oil, 20,000 ha for coconut, and 5,000 ha for fruits and vegetables. Approximately 10,300 families are engaged in rice production. We organised a programme on "Climate change: A threat to farmers" in collaboration with IADA. We addressed and explained some climate change adaptation programmes such as adopting new technology, changing planting dates, improvement of irrigation system, using different crop varieties, planting trees, soil conservation, and water harvesting, etc. to the farmers. We also discussed the benefits of adaptation. For example, adaptation helps to sustain or increase agricultural production, increase household incomes, enhance environmental services, protect the asset base, and keep less vulnerable to extreme weather events. All farmers in the study area were invited. The programme was designed with awareness building among the farmers and suggested how they might cope up with climate changes. Later, we collected data through a questionnaire.

\subsection{Survey design and sampling techniques}

Face-to-face interviews were arranged to collect reliable responses from the sampled farmers. The study area is located in the IADA, Selangor, Malaysia which consists of eight areas including Bagan Terap, Panchag Bedena, Pasir Panjang, Sawah Sempadan, Sekinchan, Sg. Burong, Sg. Leman, and Sg. Nipah. Using a random sampling technique, 50 farmers were selected from those areas with a total sample size of $400(50 \times 8)$. Of the 400 , we received 385 complete questionnaires culminating in a response rate of approximately $96 \%$. The survey was conducted in mid-September, 2012. The survey was confined to IADA areas as it constitutes a prominent agricultural zone in Malaysia. The data were collected through interviews with heads of households who worked as rice farmers.

\subsection{Design of the questionnaire}

In the questionnaire, section A collected information on the farmers' socio-economic demographic profile (i.e. household size, gender, ethnic group, religion, education level, income, type of farmers, farm size and family size of the respondents). Section B enquired as to farmers' perceptions and attitudes toward climate change. Section C consisted of CVM questions to estimate farmers' WTP for an efficient adaptation programme to climate change.

\subsection{Model specification}

A regression model was developed to analyse the factors that might affect the WTP of farmers for the adaptation programme. Respondents were given a card with 22 choices corresponding to different payments to select their WTP for the programme. When the value of dependent variable is limited or censored (for example, the value of dependent variable ranges from 0 to 200 or the value cannot be less than zero, etc.), researchers normally choose Tobit regression analysis (Greene, 2012). In this study, Tobit regression analysis was selected as the evaluation method. It was assumed that the factors listed in Table 2 might affect WTP and these factors were included in the model as independent variables.

The basic model of the Tobit regression analysis is as follows:

$$
y_{i}=X \beta_{i}+\varepsilon_{i}, 0.334 \mathrm{em} \varepsilon_{i} \sim N\left[0, \sigma^{2}\right],
$$

where, $y_{i}$ refers to dependent variable, $X$ represents the independent variables, $\beta_{i}$ represents the coefficient of the independent variables, and $\varepsilon_{i}$ refers to the error term. We also calculated the truncated mean and median, the marginal effect, and the probability of WTP using the Tobit Maximum Likelihood estimation (see the details in Greene (2012)).

The independent variables that predict the probability of WTP are education, household size, farm size, income, and some motivational factors. Moreover, the basic statistics of independent and dependent variables used in the Tobit regression are given in Table 3. Similarly, statistical analysis was employed to analyse the socio-economics and motivational factors which influence farmer's WTP for climate change adaptation. 
Table 2. Variables used in the Tobit regression model.

Tableau 2. Variables utilisées dans le modèle de régression Tobit.

\begin{tabular}{|c|c|c|}
\hline Variables & Description of the variables & Category \\
\hline Dependent variable:Willingness to pay (WTP) & $\begin{array}{l}\text { Willingness to pay (WTP) for } \\
\text { climate change adaptation }\end{array}$ & Ranges from RM 0 to RM 200 \\
\hline Education & Educational background & $\begin{array}{l}1=\text { No formal education, } 2=\text { Primary, } \\
3=\text { Secondary, } 4=\text { Tertiary, } 5=\text { University }\end{array}$ \\
\hline Household size & Number of household members & \\
\hline $\begin{array}{l}\text { The environment has the right to be protected } \\
\text { irrespective of the costs }\end{array}$ & Motivational factors for WTP & $\begin{array}{l}1=\text { Strongly Disagree, } 2=\text { Disagree, } 3=\text { Neutral, } \\
4=\text { Agree and } 5=\text { Strongly Agree }\end{array}$ \\
\hline Impacts on agricultural production & & $\begin{array}{l}1=\text { Strongly Disagree, } 2=\text { Disagree, } 3=\text { Neutral }, \\
4=\text { Agree and } 5=\text { Strongly Agree }\end{array}$ \\
\hline Concern for the risk posed by climate change & & $\begin{array}{l}1=\text { Strongly Disagree, } 2=\text { Disagree }, 3=\text { Neutral } \\
4=\text { Agree and } 5=\text { Strongly Agree }\end{array}$ \\
\hline
\end{tabular}

\section{Results and discussions}

\subsection{The socio-economic characteristics of the respondents}

Table 3 summarises the sampled farmers' socio-economic characteristics, which align well with the limited data available for the population of Selangor. The age distribution of farmers is ranged between 18 and over 60 years. The highest percentage of the farmers $(50 \%)$ was from the age group between 31 to 45 years followed by the age group of 46 to 60 years $(39 \%)$. Moreover, the study found that most of the farmers (approximately 45\%) had secondary school degree; however, almost $12 \%$ of total farmers had no formal degree. Furthermore, we found that the highest percentage of the farmers (34\%) had an income ranging between RM 2000 to RM 4000 per month. Among the sampled farmers, less than 3\% had an income above RM 10,000 and more than 7\% had an income below RM 2000. The findings of the socio-economic demographic breakdown show that age, education, and income distribution of farmers might have a positive impact on the adoption of new production techniques.

\subsection{Motivational factors for willingness to pay}

We asked the farmers to rank the motivational factors which might encourage their willingness to pay for an efficient adaptation programme to climate change. The motivational factors were ranked from the scale of 1 to 9 in accordance with importance. Of the 385-farmer sample, approximately $74 \%$ stated their willingness to pay for the programme. The percentage of WTP for the adaptation programme is higher
Table 3. Socio-economic demographic profiles of the respondents $(n=385)$.

Tableau 3. Profil socio-économique et démographique des participants $(n=385)$.

\begin{tabular}{lrc}
\hline Demographics profiles & Frequency & Percentage \\
\hline Age & & \\
18-30 years & 27 & 7.02 \\
31-45 years & 194 & 50.38 \\
46-60 years & 150 & 38.96 \\
60 years and above & 14 & 3.64 \\
Educational background & & \\
No formal education & 46 & 11.95 \\
Primary & 73 & 18.96 \\
Secondary & 173 & 44.94 \\
Tertiary & 82 & 21.30 \\
University & 11 & 2.85 \\
Income & & \\
$<$ RM 2000 & 28 & 7.27 \\
RM 2000-RM 4000 & 130 & 33.77 \\
RM 4000-RM 6000 & 115 & 29.87 \\
RM 6000-RM 8000 & 80 & 20.78 \\
RM 8000-RM 10,000 & 22 & 5.71 \\
Above RM 10,000 & 10 & 2.60 \\
Total & $\mathbf{3 8 5}$ & $\mathbf{1 0 0}$ \\
\hline Sourc: field survey 2012 & & \\
\hline
\end{tabular}

Source: field survey 2012. 
Table 4. Ranking of motivational factors for willingness to pay $(n=285)$.

Tableau 4. Classement des facteurs de motivation pour la volonté de payer $(n=285)$.

\begin{tabular}{|c|c|c|c|c|}
\hline Motivational factors & $\%$ of perception & Mean & Std. Dev & Ranking \\
\hline I feel responsible to finance for adaptation programme to climate change & 80 & 3.28 & 0.68 & 5 \\
\hline I care about the environment in general & 76 & 3.25 & 0.66 & 4 \\
\hline To reduce unexpected future economic costs & 75 & 3.32 & 0.75 & 7 \\
\hline To protect next generations & 73 & 3.34 & 0.76 & 9 \\
\hline To protect flora and fauna on this earth & 65 & 3.29 & 0.70 & 6 \\
\hline The environment has the right to be protected irrespective of the costs & 60 & 3.31 & 0.68 & 8 \\
\hline Concern for the risk posed by climate change & 78 & 3.24 & 0.87 & 3 \\
\hline
\end{tabular}

Source: author's calculation.

than those found among farmers in other countries, such as $71.6 \%$ for Ghana (Acquah, 2011). Based on the results, $85 \%$ of the farmers in Selangor were willing to pay for a programme because they were motivated by the fact that climate change has an impact on agricultural production. More than $80 \%$ of the respondents were motivated to finance the programme to avoid future natural disasters. Furthermore, $78 \%$ of the respondents were concerned for the risks posed by climate change which was another motivational factor. The remaining motivating factors along with the above are stated in Table 4.

\subsection{Factors for not willing to pay}

Farmers were asked to give reasons for not willing to pay for the adaptation programme. Based on our results, approximately $26 \%$ of the respondents were not willing to pay for the programme. The percentage of not WTP for the adaptation programme in our sample is lower than those found among farmers in other countries, 28\% for Ghana (Acquah, 2011). The majority of the respondents $(20 \%)$ preferred to spend their money on other things rather than the adaptation programme. Among the respondents, only $10 \%$ did not believe in climate change. Moreover, $16 \%$ of the farmers considered it the government's responsibility and $12 \%$ did not believe that such programme would have real impact. However, we considered these two groups as protesters, thus, we excluded

Table 5. Factors for not willing to pay.

Tableau 5. Facteurs du refus de payer.

\begin{tabular}{ll}
\hline Factors & $\%(n=100)$ \\
\hline I don't believe in climate change & 10 \\
My income is too low & 14 \\
Climate change does not affect me or my family & 15 \\
I prefer to spend my money on other things & 20 \\
I don't believe that such a programme would have & 12 \\
any real impact & 16 \\
It is government's responsibility & 13 \\
Climate change issue is not important & \\
\hline
\end{tabular}

Source: author's calculation. the respondents of the two groups in our further analysis. All the factors of not willing to pay are summarised in Table 5.

\subsection{Statistics of willingness to pay}

The statistics of WTP of sampled farmers for the adaptation programme is summarised in Table 6. Farmers were asked to pick up the amount they want to pay. Of the 357 respondents, nearly $66 \%$ were willing to pay RM 5, 10, and 16 for adaptation

Table 6. The amount of willingness to pay for an efficient adaptation programme with statistics.

Tableau 6. Montant que les participants sont prêts à payer pour un programme d'adaptation efficace, et statistiques.

The amount of willingness to pay for an efficient adaptation programme $(n=357)$

\begin{tabular}{lrcc}
\hline Items & & Frequency & Percentage \\
\hline RM & 0 & 72 & 20.17 \\
RM & 5 & 106 & 29.69 \\
RM & 10 & 75 & 21.01 \\
RM & 16 & 52 & 14.57 \\
RM & 25 & 22 & 6.16 \\
RM & 35 & 12 & 3.36 \\
RM & 45 & 10 & 2.80 \\
RM 200 & 8 & 2.24 \\
Total & 357 & 100
\end{tabular}

Statistics of willingness to pay $(n=357)$

\begin{tabular}{ll}
\hline Mean & 14.38 (std error of mean 1.58) \\
Median & 10 \\
Std Deviation & 29.91 \\
Skewness & 5.416 (std error of skewness 0.130$)$ \\
Kurtosis & 30.951 (std error of kurtosis 0.260$)$ \\
Minimum & RM 0 \\
Maximum & RM 200
\end{tabular}

Source: author's calculation. 
Table 7. Estimation results for Tobit model (dependent variable is WTP).

Tableau 7. Résultats de l'estimation pour le modèle Tobit.

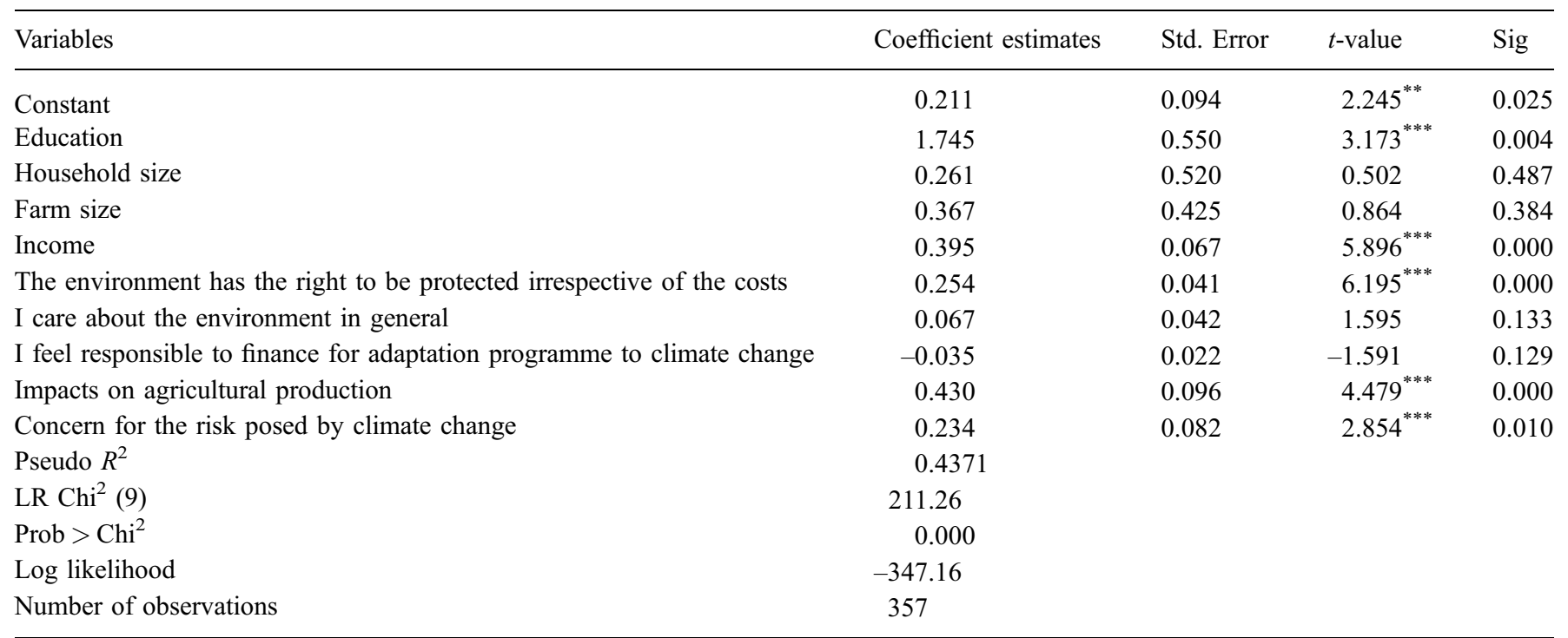

Source: author's calculation.

${ }^{* * *}$ Significant level at $1 \%,{ }^{* *}$ Significant level at $5 \%,{ }^{*}$ Significance at $10 \%$.

towards climate change. The mean is evaluated as RM 14.38 (\$4.42), and the median is determined as RM 10 (\$3.08) respectively. It is evident that the median is lower than the mean which indicates that the majority of the farmers are willing to pay less than the mean of WTP. The respondent distribution is skewed by limited high bidders.

\subsection{Tobit estimation results analysis}

The socio-economic demographic profiles of the farmers were grouped into academic qualification of the farmers, household size of the farmers, income of the farmers, and size of the farms in the regression model. Additionally, knowledge and attitude of the farmers towards climate change was used in the regression as attitudinal variables, while WTP was the dependent variable (where, the value of the WTP ranges from RM 0 to RM 200 and the total respondents are 357).

The likelihood ratio test suggested that the estimated Tobit regression model had a good fit with a statistically significant value of 211.26 at $1 \%$ with $9^{\circ}$ of freedom indicating a strong relationship between WTP and the explanatory variables (see in Tab. 7). The Pseudo $R^{2}$ or McFadden's $R^{2}$ was $44 \%$, considered as a very good fit (Srisopaporn et al., 2015). Additionally, the percentage of correct prediction can be used as a measure of "goodness of fit" (Kennedy, 2008). Thus, the nearly $90 \%$ of correct prediction showed the goodness of fit for this model. The positive coefficient values of the variables of education, household size, farm size, and income were $P=1.745,0.261$, 0.367 , and 0.395 respectively and the motivational factors like 'the environment has the right to be protected irrespective of the costs' $(P=0.254)$, impacts on the agricultural production $(P=0.430)$, concern for the risk posed by climate change $(P=0.234)$, implied that WTP was positively related with the variables as expected. However, a $t$-test was conducted in order to test the significance of the coefficients. The results of the $t$ test revealed five variables, namely education, income, the environment has the right to be protected irrespective of the costs, impacts on agricultural production, concern for the risk posed by climate change, were significant at $1 \%$ with $P<0.01$. The results showed that farmers who had education and high income were more willing to pay for the programme. These results also support the hypothesis that the WTP increases with education level and farmers' income. Earlier studies (e.g. Acquah, 2011; Yoo and Kwak, 2009) also concluded that income and education level have a positive relationship with the willingness to pay for an adaptation programme. The study suggests that some motivational factors (such as the environment has the right to be protected irrespective of the costs, impacts on agricultural production, and concern for the risk posed by climate change) have positive impact on the WTP, which supports the second hypothesis of the study.

Further, we calculated the marginal effects of each variable on the probability of positive WTP as well as on the level of positive WTP (see in Tab. 8). In both cases, WTP values were significantly influenced by education, income, the environment has the right to be protected irrespective of the cost, impacts on agricultural production, and concern for the risk posed by climate change. An increase in the level of education and monthly household income resulted in a RM 1.34 and RM 0.17 increase, respectively, in positive WTP for the efficient adaptation programme. The respondents who were mostly influenced by the motivational factors (i.e., the environment has the right to be protected irrespective of the cost, impacts on agricultural production, and concern for the risk posed by climate change) would value add to positive WTP for the adaptation programme.

Table 9 reported the mean and median values of WTP for an efficient adaptation programme. Based on the Tobit Maximum Likelihood estimation, the expected mean and median values of WTP were RM 17.2 and RM 14 respectively. Although the 
Table 8. Marginal effects of explanatory variables on probabilities and WTP: Tobit estimation.

Tableau 8. Effets marginaux des variables explicatives sur les probabilités et la volonté de payer : estimation Tobit.

\begin{tabular}{lcc}
\hline Variables & $\begin{array}{l}\text { Probabilities } \\
{[\operatorname{Pr}(\mathrm{WTP}>0)]}\end{array}$ & $\begin{array}{l}\text { WTP } \\
(\mathrm{WTP}>0)\end{array}$ \\
\hline Education & $0.042^{* * *}(0.009)$ & $1.342^{* * *}(0.370)$ \\
Household size & $0.005(0.012)$ & $0.140(0.315)$ \\
Farm size & $0.007(0.010)$ & $0.196(0.245)$ \\
Income & $0.015^{* * *}(0.005)$ & $0.165^{* * *}(0.038)$ \\
The environment has the right to be protected irrespective of the costs & $0.012^{* * *}(0.004)$ & $0.127^{* * *}(0.022)$ \\
I care about the environment in general & $0.004(0.007)$ & $0.038(0.031)$ \\
I feel responsible to finance for adaptation programme to climate change & $-0.002(0.004)$ & $-0.025(0.019)$ \\
Impacts on agricultural production & $0.006^{* * *}(0.001)$ & $0.270^{* * *}(0.056)$ \\
Concern for the risk posed by climate change & $0.005^{* * *}(0.001)$ & $0.189^{* * *}(0.046)$ \\
\hline
\end{tabular}

Source: author's calculation.

${ }^{* * *}$ Significant level at $1 \%,{ }^{* *}$ Significant level at $5 \%,{ }^{*}$ Significance at $10 \%$.

Table 9. Mean and median values of WTP with the Tobit estimation and descriptive statistics.

Tableau 9. Valeurs moyennes et médianes de la volonté de payer: estimation Tobit et statistiques descriptives.

\begin{tabular}{lcl}
\hline & Tobit & Descriptive statistics \\
\hline Mean [E(WTP | WTP $>0)]$ & 17.2 & 14.38 \\
Std Deviation & 9.33 & 29.91 \\
Median & 14 & 10 \\
Number of observations & 357 & 357 \\
\hline
\end{tabular}

descriptive statistics showed the mean and median values of RM 14.38 and RM 10 respectively, these values were lower by $19.61 \%$ (mean) and $40 \%$ (median) than the expected values from the Tobit estimation. The main reason was that the expected values of the latent variables in the Tobit estimation for zero observations were greater than zero, which is also supported by the findings of Yu and Abler (2010).

The most efficient and functioning approach to implement the adaptation programme to climate change is to help the farmers increase their income level through some other related programmes. The farmers or the farm will pay for the adaptation programme to climate change if the farm earns enough revenue and minimises the potential losses. Government and nongovernment organisations can assist the farms earn better revenues and minimise losses by providing expertise and technological support. Farmers can increase high yields and revenue while improving soil quality and biodiversity as well as protecting the habitat by adopting new technology and innovative approaches (Menter, 2012). This approach is nevertheless a longterm process. For the short term, it will be more effective to implement an efficient adaptation programme to climate change by creating better awareness of climate change issues.

\section{Recommendation and conclusion}

An efficient adaptation to climate change should be an essential part of Malaysia's development plan. Agricultural activities are mostly vulnerable to climate change. Therefore, it is crucial to assess farmers' understanding, attitudes, and willingness to pay for an efficient adaptation programme towards climate change to devise action to handle the adverse impacts of climate change on the national economy. As mentioned earlier, most respondents $(85 \%)$ confirmed that climate change has a concerning impact on their agriculture and $83 \%$ of the respondents wanted to avoid future natural disasters caused by climate change. Therefore, most felt that they are responsible to pay for the adaptation programme. However, a significant number of farmers are yet to understand the effects of climate change in the days to come on agricultural sectors. Thus, it is necessary for the Malaysian government, social institutions, banks, NGOs, and media to work hand in hand to come up with fruitful awareness programmes for farmers. The government should take initiatives to address the farmers about the risk and adverse impacts of climate change such as rising sea levels and changes in temperature, and they should motivate them to pay for the adaptation programme. These can be implemented through the adaptation training campaigns, providing technical support to farmers, and organising workshops on climate change. However, policy makers must understand how and to what extent farmers perceive and respond to the effects of climate change on the agricultural sector in Malaysia.

Furthermore, we found education, income, and farmer's behaviours are positively related to financing for an adaptation programme in the regression estimation. The result shows that additional income generating activities might encourage farmers to finance the adaptation programme. Hence, the Malaysian government could promote some special farming schemes for the farmers to generate additional revenue to adjust with adaptation financing. Subsequently, farmers could contribute to the fund maintained jointly by the local government (municipal government) and the farmers. Financial institutions such as banks, insurances, leasing firms, etc. could donate a substantial portion to the fund as a contribution of their corporate social responsibility (CSR). All efficient adaptation programmes for the farmers in the municipality could be implemented using that fund. Adaptation should be designed in such a way that the programme would be successfully carried out to ensure economic efficiency to emphasise agronomic techniques (e.g. irrigation, drought-resistant plants and early maturing varieties and so on) which might mitigate production 
risk considering extreme weather situations. If these implications are executed properly by the policy makers, farmers would also possibly understand the effectiveness of particular adaptation policy and their behaviours towards financing for a specific adaptation programme pertaining to climate change will be improved.

Acknowledgement. The first author would like to thank the University of Malaya for funding his doctoral studies through Bright Spark Program (BSP). He would like to thank his colleagues for their comments and the anonymous reviewer(s) for his/her critical review and precious comments that help to improve the manuscript substantially.

\section{References}

Aadland D, Caplan AJ. 2006. Cheap talk reconsidered: New evidence from CVM. J. Econ. Behav. Org. 60: 562-578.

Abdullah MY. 2007. Climate change and food security, MARDI. Available at: http://www.undp.org.my/uploads/g_Food_security_ MARDI.pdf.

Acquah H. 2011. Farmers perception and adaptation to climate change: A willingness to pay analysis. J. Sust. Dev. Afr. 13: 150-161.

Alam MM, Toriman M, Siwar C, Molla RI, Talib B. 2011. Impact of agricultural supports for climate change adaptation: A farm level assessment. Am. J. Environ. Sci. 7: 178.

Arbuckle Jr JG, Morton LW, Hobbs J. 2013. Farmer beliefs and concerns about climate change and attitudes toward adaptation and mitigation: Evidence from Iowa. Clim. Change 118: 551-563.

Austin OC, Baharuddin AH. 2012. Risk in Malaysian agriculture: The need for a strategic approach and a policy refocus. J. Malay. Stud. 13: 21.

Barnes A, Islam MM, Toma L. 2013. Heterogeneity in climate change risk perception amongst dairy farmers: A latent class clustering analysis. Appl. Geogr. 41: 105-115.

Boyle KJ. 2003. Contingent valuation in practice. In: Champ PA, Boyle KJ, Brown TC, eds. A primer on nonmarket valuation. Netherland: Springer.

Carson R. 2012. Contingent valuation: a comprehensive bibliography and history. Cheltenham, UK: Edward Elgar Publishing.

Carson RT, Louviere JJ, Wei E. 2010. Alternative Australian climate change plans: The public's views. Energy Policy 38: 902-911.

Fankhauser S. 2013. Valuing climate change: the economics of the greenhouse. New York: Routledge.

FAO. 2015. A special report on crop and food security assessment mission to Swaziland. In: Pound J, Michiels J, Bonifácio R, eds. Swaziland: World Food Programme.

Gornall J, Betts R, Burke E, Clark R, Camp J, Willett K, et al. 2010. Implications of climate change for agricultural productivity in the early twenty-first century. Philos. Trans. R Soc. Lond. B Biol. Sci. 365: 2973-2989. doi:10.1098/rstb.2010.0158.

Greene WH. 2012. Econometric analysis, 7th ed. Upper Saddle River. New Jersey: Prentice Hall.
Initial National Communication (INC). 2000. Malaysia national communication. Ministry of Science, Technology and the Environment. United Nations Framework Convention on Climate Change.

IPPC. 2014. Summary for policymakers. In: Edenhofer O, PichsMadruga R, Sokona Y, Farahani E, Kadner S, Seyboth K, eds. Climate change 2014: Mitigation of Climate Change. Contribution of Working Group III to the Fifth Assessment Report of the Intergovernmental Panel on Climate Change.

Kennedy P. 2008. A guide to econometrics. Cambridge, Massachusetts: MIT press.

Kurukulasuriya P, Rosenthal S. 2013. Climate change and agriculture: A review of impacts and adaptations. Environ. Dep. Papers 91: 1-106.

Le Dang H, Li E, Bruwer J, Nuberg I. 2014. Farmers' perceptions of climate variability and barriers to adaptation: lessons learned from an exploratory study in Vietnam. Mitig. Adapt. Strateg. Global Change 19: 531-548.

Lobell DB, Schlenker W, Costa-Roberts J. 2011. Climate trends and global crop production since 1980. Science 333: 616-620.

Luers AL, Lobell DB, Sklar LS, Addams CL, Matson PA. 2003. A method for quantifying vulnerability, applied to the agricultural system of the Yaqui Valley, Mexico. Global Environ. Change 13: 255-267.

Menapace L, Colson G, Raffaelli R. 2015. Climate change beliefs and perceptions of agricultural risks: An application of the exchangeability method. Global Environ. Change 35: 70-81.

Menter J. 2012. Helping U.S. farmers increase production and protect the land. Yale Environ. 360: 1-3.

Rowe RD, Schulze WD, Breffle WS. 1996. A test for payment card biases. J. Environ. Econ. Manage. 31: 178-185.

Safi AS, Smith, WJ, Liu Z. 2012. Rural Nevada and climate change: vulnerability, beliefs, and risk perception. Risk Anal. 32: 1041-1059.

Singh J. 2014. Textbook of agricultural meteorology. Jaipur, India: Oxford book company.

Siwar C, Alam MM, Murad MW, Al-Amin AQ. 2009. A review of the linkages between climate change, agricultural sustainability and poverty in Malaysia. Int. Rev. Bus. Res. Papers 5: 309-321.

Srisopaporn S, Jourdain D, Perret SR, Shivakoti G. 2015. Adoption and continued participation in a public Good Agricultural Practices program: The case of rice farmers in the Central Plains of Thailand. Technol. Forecast. Soc. Change 96: 242-253. doi:http://dx.doi.org/ 10.1016/j.techfore.2015.03.016.

Stern NH, Treasury HM. 2006. Stern Review: The economics of climate change. London: HM treasury.

Tao F, Hayashi Y, Zhang Z, Sakamoto T, Yokozawa M. 2008. Global warming, rice production, and water use in China: developing a probabilistic assessment. Agric. Forest Meteorol. 148: 94-110.

Wheeler S, Zuo A, Bjornlund H. 2013. Farmers' climate change beliefs and adaptation strategies for a water scarce future in Australia. Global Environ. Change 23: 537-547.

Yoo SH, Kwak SY. 2009. Willingness to pay for green electricity in Korea: A contingent valuation study. Energy Policy 37: 5408-5416.

$\mathrm{Yu} \mathrm{X}$, Abler D. 2010. Incorporating zero and missing responses into CVM with open-ended bidding: Willingness to pay for blue skies in Beijing. Environ. Dev. Econ. 15: 535-556.

Cite this article as: Banna H, Afroz R, Masud MM, Rana MS, Koh EHY, Ahmad R. 2016. Financing an efficient adaptation programme to climate change: A contingent valuation method tested in Malaysia. Cah. Agric. 25: 25003. 